\title{
Understanding science: when metaphors become
} terms

\section{Kathryn English}

\section{(2) OpenEdition}

1 Journals

Electronic version

URL: http://journals.openedition.org/asp/2800

DOI: $10.4000 /$ asp. 2800

ISSN: 2108-6354

\section{Publisher}

Groupe d'étude et de recherche en anglais de spécialité

\section{Printed version}

Date of publication: 1 December 1998

Number of pages: 151-163

ISSN: 1246-8185

\section{Electronic reference}

Kathryn English, « Understanding science: when metaphors become terms », ASp [Online],

19-22 | 1998, Online since 13 March 2012, connection on 30 April 2019. URL : http:// journals.openedition.org/asp/2800 ; DOI : 10.4000/asp.2800

This text was automatically generated on 30 April 2019.

Tous droits réservés 


\title{
Understanding science: when metaphors become terms
}

\author{
Kathryn English
}

\section{Introduction}

1 Terminology theory and metaphor theory can be mutually enriching. Metaphor theory uses the concept of assumptive frameworks, as well as source and target fields to clarify how metaphors function. Terminology theory describes conceptual space, and defines terms in a way that could subsequently explain them. Within the framework of Language for Specific Purposes, concepts roam from one field to another and this illustrates the need for a pragmatic perspective to define meaning. We will first examine how metaphor theory and terminology can work together to facilitate access to scientific concepts via description, explanation and definition. We will then explore in more detail the use of assumptive frameworks in relativist or defined (demetaphored) contexts.

\section{Metaphor theory and learning in the sciences}

Students learning science need to associate theoretical descriptions and explanations of how things in the universe work with common sense, or knowledge derived from everyday experience. This process builds up background knowledge or theory and can provoke what philosophers refer to as intuition dissonance, when common sense and theory conflict. Resolution of dissonance requires retracing historical steps or using heuristic devices of rationalisation. For example, understanding the heliocentric universe (with the sun at the centre) makes more sense once one has understood the ways in which the geocentric model is inadequate. On the other hand we can all understand how easy it is to believe that the Sun might revolve around the Earth since we see it rise from the East and set, reliably, in the West.

3 Contemporary metaphor theory was born within the context of analytical philosophy. In his seminal article entitled "Metaphor" the American philosopher, Max Black (1955) 
introduced the concept of assumptive frameworks or systems of associated commonplaces to describe how intuitively dissonant statements can be explained in understandable words and then shared with others using the traditional rhetorical device known as metaphor. An assumptive framework allows us to filter out what appears to be useless information -the unused part of metaphor- and focus on what we deem pertinent for the statement, text, or problem at hand. Take, for example, this famous metaphor, expressed as a truth value, "Man is a wolf". We express the new or unusual, the target, in terms of concepts which are better known and assumed to be commonly shared, the source (Fig. 1a). When several source fields interact, a new mental space is opened. This is known as conceptual blending (Fig.1b). (Rohrer 1997; Fauconnier 1997)

Figure 1. A visual representation of Black's interaction hypothesis

Figure 1a

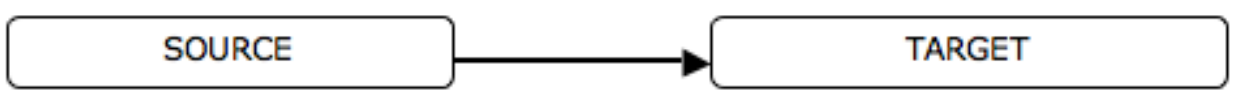

Figure $1 \mathrm{~b}$

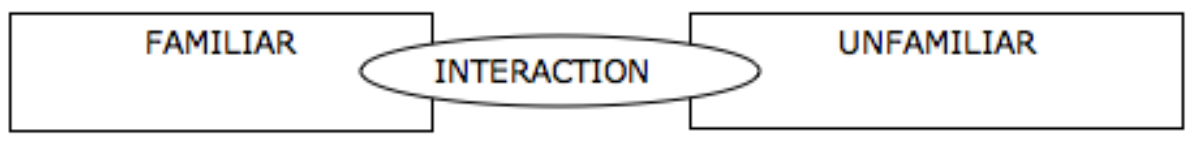

4 In the example above, we describe the cruelty of mankind by activating a common assumptive framework. We automatically filter out information which is unused (fourfooted, furry, having fangs, etc.) and concentrate on a highly-specific and tailor-designedfor-the-task-at-hand system of associated commonplaces. In this case we focus on the characteristics of being wild, ferocious, dangerous (Fig.2). It doesn't really matter if what we assume about something, and therefore focus on, is inaccurate. Are wolves really fierce? Zoologists indicate the contrary; wolves are not fierce but rather cowardly mammals. Such comparisons rely on a common cultural background which is currently under examination in the Figurative Language Network discussion list ( fln@mailbase.ac.uk). In fact, the wolves we know are literary creatures. They come from folk tales or comic strips. This reinforces their character stereotype at the expense of more objectified dictionary definitions.

Figure 2. When a metaphor is operational we focus on a selection of features and this activates a perspective or opens a new mental space.

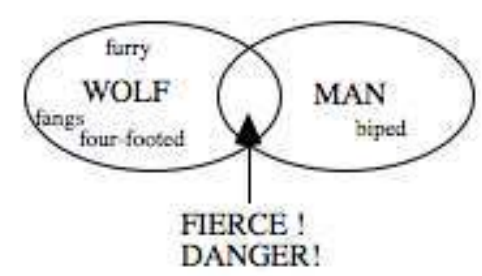

5 However, as with any statement, it is the pragmatic perspective that defines meaning. A point of view is essential to grasping any metaphor. Misunderstood or spoiled metaphors are frequently the result of differing interpretations across cultures. Language teachers know and use the concept of cross-cultural perspectives on a daily basis. They 
instinctively take into account the fact that someone is speaking to someone else about a given subject. The context designates grammatical subjects, situates time frames, determines which articles are used or provides naturally correct prepositions. In a similar way, scientific models also appear to refer to assumptive frameworks -those in which their legitimacy is grounded.

Learning in the technical sciences entails the appropriation of concepts and precise quantification techniques. This, however, should in no way exclude metaphoric qualitative explanation and the activation of potentially contradictory systems of associated commonplaces. More concretely, scientific texts contain elements of description, definition and explanation. All three dimensions interact to produce meaningful communication. We will examine them below.

\subsection{Description}

7 Description of phenomena can come in the form of verbal rules. Electricity flows from the negative to the positive pole. The literal description of Ohm's law is current $=$ voltage/ resistance or $(\mathrm{I}=\mathrm{V} / \mathrm{R})$. The description of processes may also list the order of events required to reach a given (desired) stage of development. For example, in dataprocessing, instructions can be given in a strictly linear, hierarchical and sequential form, such as in the MS-DOS computer operating system. Alternatively, instructions may be presented metaphorically, via the more user-friendly, Graphic User Interface (GUI) depicting a desktop. The MAC OS and Windows 95 operating system use these metaphorical techniques to make complex computer technology seem simple to ordinary users.

8 The underlying assumption behind the linear vision of description is that the world exists in an objectively literal form and the scientist's task is to find straightforward ways of describing it. Similarly, the linguist working in specialised languages tends to identify objective observation with literal language.

Science is supposed to be characterised by precision and the absence of ambiguity, and the language of science is assumed to be correspondingly precise and unambiguous -in short, literal. (Ortony 1993: 1)

9 However, literal language is not necessarily objective and literal statements certainly do not guarantee objectivity. Attitudes about language itself are often expressed by linguists in terms of generic metaphors. The conduit metaphor, presented by M. Reddy of Columbia University (in Ortony 1993: 167) illustrates how this objective and literal view of language may operate. Language is seen as a carrier of ideas, values, and beliefs. The listener unpacks the message to take out what was in it. Reddy provides an extensive list of expressions in English to support this idea. A selection of his examples follow:

You have to put each concept into words very carefully.

Insert those ideas elsewhere in the paragraph.

Try to pack more thoughts into fewer words.

Try to get your thoughts across better.

10 Scientific description and attitudes toward language share the notion that both seem to be framed by the same objectivist paradigm. Learning to use or already using a language is mistakenly assumed to be like learning a scientific concept. It is a question of transmitting information from someone who knows to someone who doesn't know yet. 
11 Substantial grassroots work in the ESP field (autonomous learning, learner empowerment, guided autonomy), however, points to a different perspective. It is hardly necessary in these pages to suggest that language learners do not merely memorise words or rules of grammar. More emphatically, the physiopsychologist J.F. Lambert, suggested during the CERCLES conference in Bordeaux 1997 that using language involves action, "Pour apprendre une langue il faut la prendre". In other words, learning a language necessarily entails learner empowerment. This would imply activating or modifying his/ her assumptive frameworks.

12 The use of language (Langue), and its instantiation (Parole), is testimony to effective appropriation. For this, learners need more than to cram the formula behind it. They require an understanding of the causes and effects of language. In the world of science this would be formulated as the concept of explanation.

\subsection{Explanation}

13 Explanation differs from description in that it seeks to elucidate the mechanisms that underpin the descriptive rules. Recourse to instructive metaphor is frequent when abstract concepts must be learned. Richard E. Mayer from the University of California at Santa Barbara quotes a well-known scientific textbook which explicitly compares electricity to water flowing in pipes to explain Ohm's law.

To understand this idea, compare the pictures of pipes. [Pictures show water coming out of a narrow pipe and water coming out of a wide pipe.] The only difference in the pipe is their diameters. The pump pushes water equally in both cases. But more water passes through the pipe with the large opening. The larger pipe offers less resistance to the flow of water than the smaller pipe. In a similar way, more current flows through a conductor with less resistance than through a conductor with more resistance. (Mayer in Ortony 1993: 562)

14 Clearly the verbal description of Ohm's law, given in section 1.1, is shorter, more economic than the wordy explanation. However, the re-deployment of the visual analogy with pipes allows the students to intuitively grasp the abstract concepts and make the verbal law, i.e. the law of physics expressed in words, real. In the case of the well-known metaphor, Internet-is-an-information superhighway, larger cables are frequently depicted as transmitting information at a faster rate. In reality, just like the truth value of wolves being fierce, the modern, narrow cables use higher bit rates to carry more information. This 'intuitively dissonant' metaphor functions well -even if the underlying reality is false. So, although succinct mathematical notation is sometimes unavoidable, so are the half-truths of metaphor which often underpin the equations.

...Description without explanation is incomplete ... literal precision without models

or metaphors of the underlying mechanisms is sterile. (Mayer in Ortony 1993: 566)

Description and explanation go hand in hand in both developing concepts and communicating them to others. But, on the other hand, definitions, are used to situate and limit the conceptual space designated by specific concepts. They tie the metaphorical to the literal and situate mental spaces within flexible terminological trees.

\subsection{Definition (demetaphoring)}

16 It is well known that definitions of scientific concepts are often difficult or even impossible to understand for the uninitiated reader. A selection of characteristics is 
retained in order to distinguish the generic hyperonym from a more specific hyponym. Descriptions are therefore trimmed to their necessary and sufficient minimums and explanation is considered superfluous. Take for example this definition, in French, of the concept cellule in topology, a field of mathematics dealing with Euclidean spaces.

Table 1

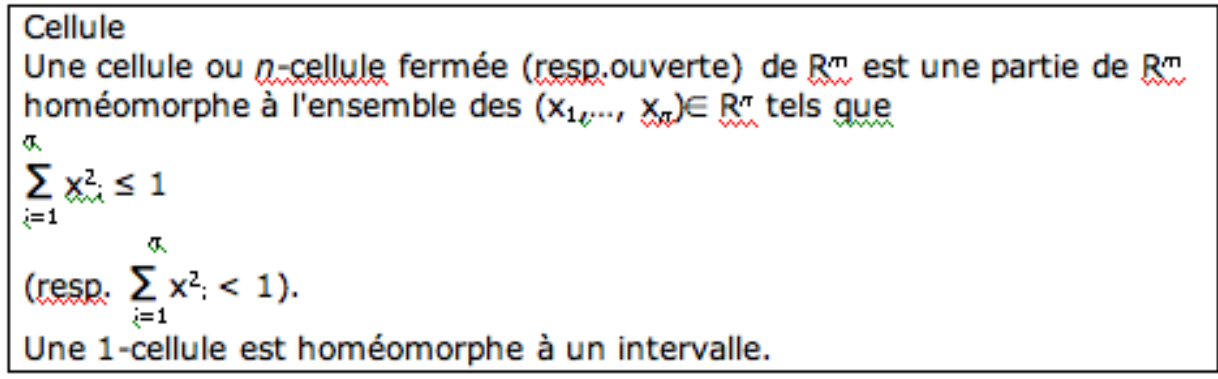

17 It is assumed that the person consulting the mathematics dictionary where this definition was given possesses sufficient conceptual baggage to understand the lexical and notational items at work. For the linguist more explanation may be necessary. He may look up another dictionary, which makes learning long and laborious. In addition, definitions usually deal with dead metaphors as we will see below. The concept cell involves a specified area which can assume any shape and is defined by its interior, its boundary (homeomorphic or not) and this also implies the existence of an exterior. For example, a lump of clay can assume any shape, but its overall volume or topological space remains constant. It is homeomorphous if there are no holes or corners in its boundary. The concept and its name, cell, appear to have phenomenological or experiential and metaphoric origins. ${ }^{1}$ In his well-known book, Metaphors We Live By, the American linguist George Lakoff, lays out the linguistic basis for metaphoric grounding using extensive examples drawn from everyday, non specialised language. For example, the /containe/r scheme reflects one of the most fundamental human instincts -that of territory.

We are physical beings, bounded and set off from the rest of the world by the surface of our skins, and we experience the rest of the world as outside us. Each of us is a container, with a bounding surface and an in-out orientation. (Lakoff \& Johnson 1980: 29)

Thus, the grammar of everyday language is testimony to the relation between language and an individual perception of reality. In a sentence, content words and grammatical words interact. This interactive association introduces a specific framework or series of shared commonplaces. Here are some of Lakoff's examples (1980: 30-31):

- The Visual Field = a container The ship is coming into view. I have him in sight. (...)

- Events, Actions, Activities, and States = container object

Are you in the race on Saturday?

Halfway into the race, I ran out of energy. (...)

- Activities viewed as containers

In washing the window, I splashed water all over the floor. [...] 
notion is subsequently transformed into a standardised term which, via definition, is granted the prestige of literal language. The standardised definition confers official term recognition to what may have previously been a fluctuating value due to visibly metaphorical expression. The act of 'demetaphorisation' is the product of a discourse community which includes not only authors and readers but also a specified communication situation which would guarantee reference to the shared assumptive frameworks mentioned above.

However, the concept cellule is subject to multiple interpretations according to the specific purpose required by the user. In one case I consulted a pure mathematician who felt the concept could not be represented visually since, by definition, it exists in $n$ dimensions and can take on any form. Later, an engineer deployed the same mathematical notation to represent the concept visually. This representation is given in figure 3.

Figure 3. One possible, two-dimensional representation of the concept cell in topology

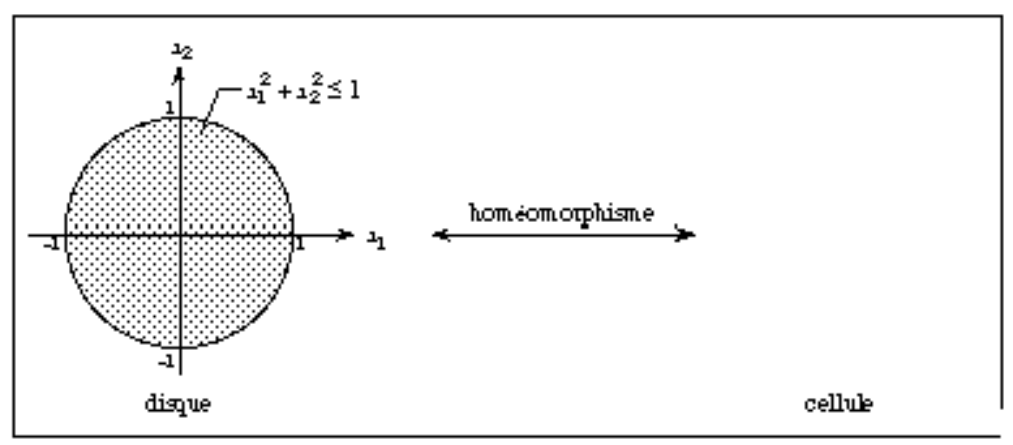

Is either one 'correct'? The mathematician is perhaps correct in respecting to the letter the notational definition of $n$ dimensions. The engineer needs to bend the truth to give a usable, visual representation. Both use the concept for their own specific purposes and interpret the notation according to their own assumptive frameworks. The mathematical notation is however, considered unambiguous. It can be applied, or reproduced to give predictable results.

But how do students go about learning both precise formulae as well as reductive or blatantly false metaphoric descriptions? From the perspective of defining dissonant assumptive frameworks it is interesting to note how students read verbal or notational information.

\section{Using assumptive frameworks to retain scientific concepts}

We have seen how metaphor can be used to describe and perhaps even create a new conceptual, mental space. Water flowing through pipes, imaginary information highways and graphic user interface (GUI) desktops or imaginary, homeomorphic boundaries present an approximate image but a representation that is sufficient to access some understanding of the abstract concepts under consideration. A strong analogy can help the student learn an underlying process and this approach can be refined by quantifying the situation using different mathematical notation. 
Research in the cognitive sciences has suggested that the mental model students use, i.e. the mental metaphor, influences how they go about formulating mathematical notation. For example, students who used the flowing water metaphor to solve problems related to Ohm's law performed differently than those who used a different, teeming crowd metaphor (where current is seen as particles clinging together). Macintosh users automatically file metaphorical dossiers in metaphorical trash cans which become plump when filled. MS-DOS users learn how to delete by checking a codebox. The metaphor structures the argument, albeit unwittingly.

Not only do formulations differ according to the metaphor in use but information appears to possess different priority levels. Research on expertise in scientific problem solving suggests that experts

[...] rely initially on qualitative reasoning and, if the problem requires it, employ quantitative models after they had [sic] analysed the problem in conceptual, qualitative terms. (White \& Frederiksen,1987: 281)

Analysis of students' eye movements when solving arithmetic word problems show that successful students look first at the words in the problem before looking at the numbers (Hegarty, Mayer \& Green 1992: 76-84). In scientific problems, it would seem that solving qualitative reasoning precedes quantitative calculation. Curiously then, the function of explanation appears to precede description.

Unless one presupposes that most of the work of grasping the metaphor has already occurred , the 'literal' definition may not do the trick at all. (Petrie 1976)

Assumptive frameworks are essential to the interpretation of metaphors as well as the appropriation of scientific models. Highlighting essential characteristics and screening unused portions of metaphors (the furry, four-footedness of wolves in the "Man is a wolf" metaphor), not only conveys the message but puts a living, culturally-grounded author behind it. The economy of language, a defining characteristic of LSP, is preserved by the automatic activation of a common assumptive framework. The conventional transparent windowpane metaphor used to describe scientific prose, has given way to a discourse umbrella, which more accurately describes the situation of a technical author, a language teacher, or a student all working within their own series of assumptive frameworks. Their interaction takes place within a defined setting, or an assumed communication situation which can range from the classroom to the technical journal. It is their shared expectations that foster understanding.

this section we have examined how metaphors can provide the descriptive and explanatory elements which are lacking in formal definitions. Learners and experts use both figurative, qualitative analysis as well as literal, quantitative formulation. However, even formal notation, as illustrated by the use of the concept cell in topology, is subject to differing interpretations according to the specific purposes of the language/concept user.

In the following section we will examine some consequences of the persistence of the view of specialised language in light of the transparent windowpane metaphor. This outdated metaphor or communication paradigm seriously underestimates the impact of situational interpretation, instantiation or Parole in specialist discourse. 


\section{Ignoring assumptive frameworks}

31 We have seen that scientific concepts require formal notation and definition, but may also need metaphorical description and explanation. Students focus first on essential information and they are the ones to judge what is essential since they are the final consumers of a text. In other words, the learner establishes his own approach to a text and that defines what user expectations are. The instantiation of Language, the industry of Parole, uses the transformational capacities of metaphor to generate boundaries of meaning. Metaphor or nomadic concepts, which according to Isabelle Stengers (1987) are notions borrowed from other fields, operate within these assumptive frameworks. We will examine some consequences of this approach below.

\subsection{Metaphors in a 'relativist' context}

Emerging technologies require new words and frequently borrow from other fields which may be contiguous or totally unrelated. What features or defining characteristics do biological cells and mathematical cells share? Alternatively, what do the words "syntax", "semantics", "grammar" mean when the computer scientist refers to them instead of the (natural) language teacher? In nearly all cases, meanings expand, contract or are reduced due to their transfer through differing assumptive frameworks. The French philosopher, Paul Ricoeur, in a series of dialogues with the neuroscientist J.-P. Changeux, refers to this as semantic duality.

De cette hypothèse de travail qui rend possible un échange d'informations et d'arguments entre philosophes et scientifiques, je tirerai une maxime, non de complaisance, mais de concession: face à des connexions bien établies, le scientifique s'autorise lui-même -ou plutôt est autorisé par le consentement tacite de la communauté scientifique- à introduire dans ses modèles explicatifs des explications mixtes abrégées qui démentent le dualisme sémantique. Ainsi le scientifique s'autorise-t-il à dire que le cerveau est 'concerné' par tel ou tel phénomène mental, qu'il y est 'impliqué', qu'il est 'responsable de'. (...) Pour le philosophe, grand lecteur de textes scientifiques, c'est un devoir d'ajouter la tolérance sémantique à la critique sémantique; de ratifier pratiquement ce qu'il dénonce sémantiquement. (Ricoeur 1998: 55) (my italics)

Is the scientist lying when he states that the brain is "concerned"? Or is it his subjective construction of language and therefore relative vision of truth? For the French semanticist, Robert Martin, this instantiation of language reflects one's universe of beliefs which is constrained by the concept of the individual -the univers de croyance of the given person. Martin uses the notation Uje to illustrate this semantic value.

Le propre de la vérité langagière -constatation banale mais qui n'en est pas moins décisive- est une vérité prise en charge par un sujet. Un énoncé est vrai pour quelqu'un. Tout l'effort du locuteur consiste à faire admettre ce qu'il croit être vrai. Peu importe que le locuteur mente: aux yeux du linguiste est vrai ce que le locuteur asserte, la présomption étant celle de la sincérité. Peu importe que le locuteur se trompe, que ce qu'il dit être vrai ne corresponde pas aux données de l'univers. Une assertion véhicule en tant que telle sa propre vérité ; celle-ci vaut à tout le moins à l'intérieur d'un univers dont le locuteur -à tort ou à raison, de bonne foi ou nonse porte garant. (Martin 1992: 38) (my italics)

Clearly then, the truth value of a statement, be it literal or metaphorical, lies in the eye of the beholder. 


\subsection{Metaphors in a demetaphored context} mathematical concepts used to describe humanity. He might well be in complete ignorance of these mathematical concepts. Rather he would use them as touches of paint to approach some form of qualitative understanding - such as the analogy of modelling clay for cell in topology, or flowing water for electricity. The successful student would refer to his own universe of belief, his Uje to access Lacan's description of the 
subconscious. One need not know about the quality of the clay or the heat of the water to foster a qualitative approach. Accessing Lacan's text requires the attribution of a more contextual, relative value for these adopted and thereby distorted terms. Few scholars read Lacan to learn math. Sokal and Bricmont seem to expect all uses of math to be rigorously true -although, from the point of view of the humanities, would it not be rather worrisome to require an understanding of the subconscious in terms of absolute values? Emerging theories in the humanities, literary criticism, psychology or the special fields of linguistics require new concepts and researchers grapple for words to describe them. Borrowing terms from other sciences is one way of bridging this gap.

\section{Conclusion}

Metaphor poses specific problems for both onomasiologically-oriented terminology theory and applied terminography. Traditional terminological tools identify relations between concepts (generic to specific) and link monosemic terms to them via definition. The other partners of the didactic process description and explanation, are more explicitly metaphoric and therefore more difficult to process on information-lean term files. Contemporary metaphor theory has developed tools to account for metaphor; source and target fields, assumptive frameworks, and systems of associated commonplaces. Behind the precise terminology of a given scientific field, there are living root metaphors which structure the comprehension of phenomena. Metaphor theory can help shed light on some of the ambiguous aspects of terminological work. For example, is it the specific purpose of a text that establishes the legitimacy of its metaphors? Or is their validity grounded in an infinitely regressive, outside authority with a putative bird's eye view.

We have seen that were a student to apply an excellent understanding of mathematics to the study of Lacan he would be bound for failure. By teaching a language aren't we also trying to learn the language of otherness - a different set of absolute or relative values? Learning more than words and conventions of discourse can lead to more flexible interpretative skills - and a new way of seeing things. Reading for specific purposes implies this non-neutral approach to text. It implicitly recognises the legitimacy of the author's position.

Assumptive frameworks and systems of associated commonplaces can help situate new knowledge and adapt our previous way of seeing things. They can also, at least theoretically, account for modifications in language use. Metaphors challenge the status quo. Theoretical advances account for the way metaphors work and make explicit what is considered literal within each designated discourse community. In this way metaphor theory and terminology theory could be of mutual benefit to each other. 


\section{BIBLIOGRAPHY}

Black, Max. "Metaphor". Proceedings of the Aristotelian Society, N.S. (1954-55), 273-294.

Bouvier, A., M. George \& F. Le Lionnais. 1993. Dictionnaire des Mathématiques. Paris: Presses Universitaires de France.

Changeux, Jean-Pierre \& Paul Ricœur. 1998. La nature et la règle : Ce qui nous fait penser. Paris: Éditions Odile Jacob.

Fauconnier, Gilles \& Mark Turner.1997. "Conceptual integration and formal expression”. Journal of Metaphor and Symbolic Activity 10/3 http://darkwing.uoregon.edu/ rohrer/metaphor.html/ \#papers

Green, Thomas F. 1993. "Learning without metaphor”. In Ortony, Andrew (ed.), Metaphor and Thought 2nd ed. New York: Cambridge University Press.

Hegarty, M., R.E. Mayer \& C.E. Green.1992. "Comprehension of arithmetic word problems. Evidence from students' eye movements”. Journal of Educational Psychology 84, 76-84.

Lakoff, George and Mark Johnson. 1980. Metaphors We Live By. Chicago, IL: University of Chicago Press.

Martin, Robert. 1983. Pour une logique du sens, Paris: Presses Universitaires de France.

Mayer, Richard E. 1993. “The instructive metaphor. Metaphoric aids to students' understanding of science”. In Ortony, Andrew (ed.), Metaphor and Thought, 2nd ed. New York: Cambridge University Press.

Ortony, Andrew (ed.). 1993. Metaphor and Thought, 2nd ed. New York: Cambridge University Press.

Petrie, H.G. 1976. "Metaphorical models of mastery: Or how to learn to do the problems at the end of the chapter in the physics textbook". In Cohen, R.S., C.A. Hooker, A.C. Michalos \& J.W. van Evra (eds.), Proceedings of the Philosophy of Science Association, 1974. Dordrecht, Holland: D. Reidel.

Reddy, Michael J. 1993. “The Conduit Metaphor”. In Ortony, Andrew (ed.), Metaphor and Thought, 2nd ed. New York: Cambridge University Press.

Rohrer, Tim. 1997. "Conceptual Blending on the Information Highway: How Metaphorical Inferences Work”. In International Cognitive Linguistics Conference '95 Proceedings, v.2 Amsterdam: John Benjamins. http://darkwing.uoregon.edu/ rohrer/metaphor.html

Sokal, Alain \& Jean Bricmont. 1997. Les impostures intellectuelles. Paris: Éditions Odile Jacob. Stengers, Isabelle (ed).1991. D'une science à l'autre. Des concepts nomades. Paris: Éditions du Seuil. Temmerman, Rita. 1995. "The process of revitalisation of old words: 'Splicing', a case study in the extension of reference". Terminology $2 / 1,107-128$.

White, B.Y. \& J.R. Frederiksen. 1987. "Qualitative models and intelligent learning environments". In Lawler,, R.W. \& M. Yazdani (eds.), Artificial intelligence and education (vol. 1). Norwood, NJ: Ablex. 


\section{NOTES}

1. Experiential and phenomenological are similar adjectives with different genealogies. Experientialism comes from the American philosopher John Dewey (Experience and Nature, 1927), and is based on experience as a unitary aesthetic whole. Phenomenology, as defended by, for example, Paul Ricoeur, refers to the world as people experience it, opposing the myth of a noumenal world underlying experience.

\section{ABSTRACTS}

Terminology is one of the main industries of specialised communication. This paper proposes an account of how metaphors and terms interact when students learn scientific concepts and the linguistic processes that drive designation when researchers try to name emerging concepts. Selected tools of metaphor theory: assumptive frameworks, conceptual blending, source and target fields will be presented along with terminological tools including concept description and term definition which, if only theoretically, lead to monosemous, field-restricted terms.

La terminologie est une industrie de base dans la communication spécialisée. L'auteur examine l'interaction entre métaphores et termes techniques lors de l'apprentissage des concepts scientifiques, ainsi que les processus linguistiques de désignation des concepts nouveaux. Une sélection d'outils qui relève de la théorie de la métaphore : le cadre de présupposés, l'agrégation conceptuelle, les champs sources et les champs cibles est présentée. Deux outils de la terminologie, la description de concepts et la définition des termes ont pour but, au moins dans la théorie, de fournir des termes monosémiques dans un champ restreint.

\section{INDEX}

Keywords: assumptive framework, cognitive relativism, LSP, metaphor, terminology Mots-clés: cadre des présupposés, langue de spécialité, métaphore, relativisme cognitif, terminologie

\section{AUTHOR}

\section{KATHRYN ENGLISH}

Kathryn English est enseignant-chercheur à l'Institut National des Télécommunications. Elle a soutenu en 1997 une thèse intitulée « Une place pour la métaphore dans la théorie de la terminologie : les télécommunications en anglais et en français ». Elle s'intéresse à la théorie de la métaphore, à la terminologie, à la communication interculturelle et à la communication par réseaux informatiques. Kathryn.English@polytechnique.edu 